\title{
FLOOD PROTECTION ON THE ODRA RIVER IN THE SEGMENT BETWEEN NOWA SÓL AND CIGACICE
}

\author{
Magda HUDAK ${ }^{1}$, Czesław KARCZMAR ${ }^{2}$, Urszula KOŁODZIEJCZYK ${ }^{1}$, \\ Jakub KOSTECKI ${ }^{1}$ \\ ${ }^{1}$ University of Zielona Gora, Zielona Góra, Poland \\ ${ }^{2}$ C.K. ZIEMIANIN
}

\begin{abstract}
Existing river valley development methods which have been used for a significant period of time, as well as the use of land for construction of residential developments, have led to negative consequences for the environment. The agricultural use of land and its protection with hydraulic structures has restricted the natural flood area of the river. According to EU law, the risk of catastrophic flooding should be reduced, and its effects minimized. Sustainable water management determines the effectiveness of flood protection in the whole river basin.

The paper presents the flood protection on the Odra River in the segment between Nowa Sól and Cigacice, with special emphasis on the possibility of reconstructing the former flood polders in the Middle Odra Region that existed before the year 1945, including the polder in Milsko.
\end{abstract}

Keywords: flood protection, dry polder, flood polder

\section{INTRODUCTION}

The occurrence of flood risks and floods in riversides depends on a number of hydrological, meteorological, and morphological factors. These include land morphology, afforestation, soil retention levels, precipitation levels, river bed filling, and surface runoff from the river basin per unit of time.

${ }^{1}$ Corresponding author: University of Zielona Gora, Faculty of Civil Engineering, Architecture and Environmental Engineering, Institute of Environmental Engineering, Z. Szafrana st 1, 65-516 Zielona Góra, Poland, e-mail: m.hudak@iis.uz.zgora.pl 
In recent years, this risk has increased in a number of countries despite impressive technical achievements, among other things due to the huge economic and social pressure that has forced land development in floodplains [Bednarczyk, Jarzębińska, Mackiewicz, Wołoszyn 2006].

Floods in the Middle Odra Region are characterized by a mild increase and decrease of floodwaters resulting in a small and even decline in the river level, which in this area amounts to $0.22 \div 0.27 \%$ o. During the summer floods in 1997 , the Odra River flowed at a relatively slow speed (less than $2 \mathrm{~m} / \mathrm{s}$ ), which was the main reason for the long-term flooding (42 days) and resulted in the softening and washing away of material from the levees. Constant rains caused a rapid rise of the water level, and floods occurred in a number of towns and cities including Opole, Wroclaw, Kłodzko, Nysa, and Racibórz. 54 people died and approximately 1,500 families lost their houses. Material losses were estimated at $\$ 3.5$ billion. As a result of the floods, seven thousand people lost their houses and about 40,000 people lost all their property. More than nine thousand companies suffered losses due to property damage. The water destroyed or damaged 680 thousand houses, 843 schools, four thousand bridges, more than 14 thousand kilometres of roads, two thousand kilometres of railways, 613 kilometres of levees and almost 666 thousand ha of land, i.e. more than $2 \%$ of the area of the country.

In the then Zielona Gora voivodship, these floods affected 25 administrative communes. The following towns were partially flooded: Bytom Odrzański, Nowa Sól, Krosno Odrzańskie, and Słubice - by the Odra River, and Szprotawa - by the Bóbr River.

26 school buildings, $894 \mathrm{~km}$ of roads, 26 bridges, $82 \mathrm{~km}$ of levees on the Odra River and $26 \mathrm{~km}$ on the Bóbr River needed renovation and reconstruction. In addition, over 10 thousand hectares of land were flooded, which accounted for $10 \%$ of the area [Bąk, Duda 1998].

Knowledge of flood prevention problems is the basis for effective flood protection in the future. The authors of the article attempted to identify this problem in the Nowa Sól-Cigacice area. The research was based on a study of archival materials, including maps of hydrotechnical facilities from the 19th century, as well as current fieldwork.

\section{HYDROLOGICAL CHARACTERISTICS OF THE RESEARCH} AREA

The Odra River is the second largest river in Poland. Its total length is $854.4 \mathrm{~km}$, $742.0 \mathrm{~km}$ of which is the section of the Odra River flowing through Poland. The 
riverhead of the Odra River is located in the Czech Republic, in the Odra Mountains (East Sudetes), $634 \mathrm{~m}$ above sea level.

The river's length is calculated from the mouth of the Opava River located in Ostrava, $92.4 \mathrm{~km}$ from the riverhead, and is regarded as $0.0 \mathrm{~km}$ of the river's length. Near the village of Chałupki, on the 20th $\mathrm{km}$ of the river, the Odra River crosses the Polish-Czech border.

Over the distance from $408 \mathrm{~km}$ to $620 \mathrm{~km}$, the river flows through the area of the Lubuskie Voivodship (Central Odra River). The Nowa Sól-Cigacice section consists of a $44 \mathrm{~km}$ length of the Odra River. There are three tributaries there (Table 1).

Table 1. Hydrological characteristics of the Odra River sub-basin in the Nowa SólCigacice section

\begin{tabular}{|l|c|c|c|}
\hline Name of tributaries & $\begin{array}{c}\text { Distance of } \\
\text { tributaries } \\
{[\mathrm{km}]}\end{array}$ & $\begin{array}{c}\text { The length of the } \\
\text { Odra river at the } \\
\text { mouth of the } \\
\text { tributary } \\
{[\mathrm{km}]}\end{array}$ & $\begin{array}{c}\text { The area of the } \\
\text { catchment basin } \\
{\left[\mathrm{km}^{2}\right]}\end{array}$ \\
\hline Krzycki Rów & 73.5 & 433.2 & 558.9 \\
\hline Śląska Ochla & 38.2 & 442.7 & 316.6 \\
\hline Obrzyca & 65.9 & 496.4 & 808.4 \\
\hline
\end{tabular}

This section the Odra River has a regulated river bed. At the end of the 13th century, the first embankments of the Odra River were earth levees protecting local land and its owners. In the sixteenth and seventeenth centuries, there were a number of levees that had been built so chaotically that according to the opinions of the time, they did more harm than good. During the second half of the 17th century, levee associations appeared which gradually rebuilt the old levees, and, after the great flood of 1903, the levees were strengthened and expanded. The levee system was supplemented, the levees already existing before the great flood were heightened, and a number of polders were constructed in the Odra River valley [Radczuk 2008].

The water gauges in Nowa Sól and Cigacice are monitored. The largest volumes of flowing water are recorded in March (on average 200-350 $\mathrm{m}^{3} / \mathrm{s}$ ) and in June $\left(400-600 \mathrm{~m}^{3} / \mathrm{s}\right)$.

During the flood in 1997, the maximum flow rate on the Odra River was about $3,000 \mathrm{~m}^{3} / \mathrm{s}$, which was a 30 -fold increase in the flow rate in comparison with long-term average values from the previous years. Water in this segment of the Odra River, except during the periods of high water and floods, remains at low and medium levels, only reaching high levels mainly during the spring thaw and summer floods. They are determined by the water balance indices, whose 
average annual values are: precipitation - $587 \mathrm{~mm}$, drainage - about $133 \mathrm{~mm}$, drainage loss - $454 \mathrm{~mm}$.

\section{POLDERS IN THE MIDDLE ODRA RIVER BASIN}

Reducing the height of the flood wave, i.e. flattening it in a given river valley cross section, is possible through rational, integrated rainwater and surface water management in the river basin carried out above that cross section [Mikulski 1996].

Construction of polders in Western Europe is quite common. They are usually located in the middle of the river length, due to the relatively flat terrain. It is also an important ecological aspect because by increasing soil retention and proper use, they can play a useful role in the ecosystem.

Polders are intended to retain floodwaters and reduce peak flows during floods. They are areas with inlet and outlet closures (weirs, culverts, levee dams), surrounded by embankments and covered with vegetation [Tymiński 2012]. Rainwater and floodwaters are difficult to drain from the polder. For this reason, drainage ditches are necessary in this area which will drain water into the river through the bottom drain at the outlet. In exceptional cases, pumping stations are used to drain water. Polders are usually submerged once in a few or a few dozen years, which is why they are used as arable land, as well as meadows and pastures [Depczyński and Szamowski 1999].

Before the First World War, there were 12 polders on both sides of the Odra River with a total area of 12.7 thousand ha and a capacity of 104.6 million m3. At present, there are 10 polders on the Polish side of the Odra River with a total flood area of 6.4 thousand ha and a retention capacity of 75 million $\mathrm{m}^{3}$. During floods, they are flooded by inlet sluices or levee spillways [Rast, Obrdlik, Nieznański 2000]. There are three polders in the Lubuskie Voivodship (Fig. 1):

- Kiełcz-Tarnów Bycki with a capacity of 15.0 million $\mathrm{m}^{3}$,

- Połupin with a capacity of 70.0 million $\mathrm{m}^{3}$,

- Krzesin-Bytomiec with a capacity of 20.0 million $\mathrm{m}^{3}$.

All the polders were constructed at the beginning of the 20th century. Today, most of them do not serve their original purpose because they are often used as arable land, and in some cases, they are even built-up areas [Kołodziejczyk 2002].

Polders are only effective when water management is consistent across the whole river basin [Majewski 2004]. In order to decrease possible economic losses caused by the lack of water, and at the same time improve the structure of the water balance, it is absolutely necessary to restore and increase the retention capacity of the river basin [Mioduszewski 2005]. A good example is the 
reconstruction of the floodplain polders built by German engineers and existing in the Middle Odra Region in the 1940s and 1950s. These polders are: Milsko (300 ha), Tarnawa (220 ha), Pomorsko (200 ha), Brody-Bródki (180 ha), Nietkowice (310 ha), Będów (180 ha), and Połupin-Szczawno-Laski (2800 ha). Currently, the following polders exist in the Lubusz Odra River Basin: KiełczTarnów Bycki (815 ha), Połupin (4125 ha) and Krzesin-Bytomiec (1200 ha), and the following polders are planned to be constructed: Urad $\left(30\right.$ million $\left.\mathrm{m}^{3}\right)$, Słubice Górzyca (60 million $\mathrm{m}^{3}$ ) and Ługi Górzyckie (30 million $\mathrm{m}^{3}$ ) - Fig.1.

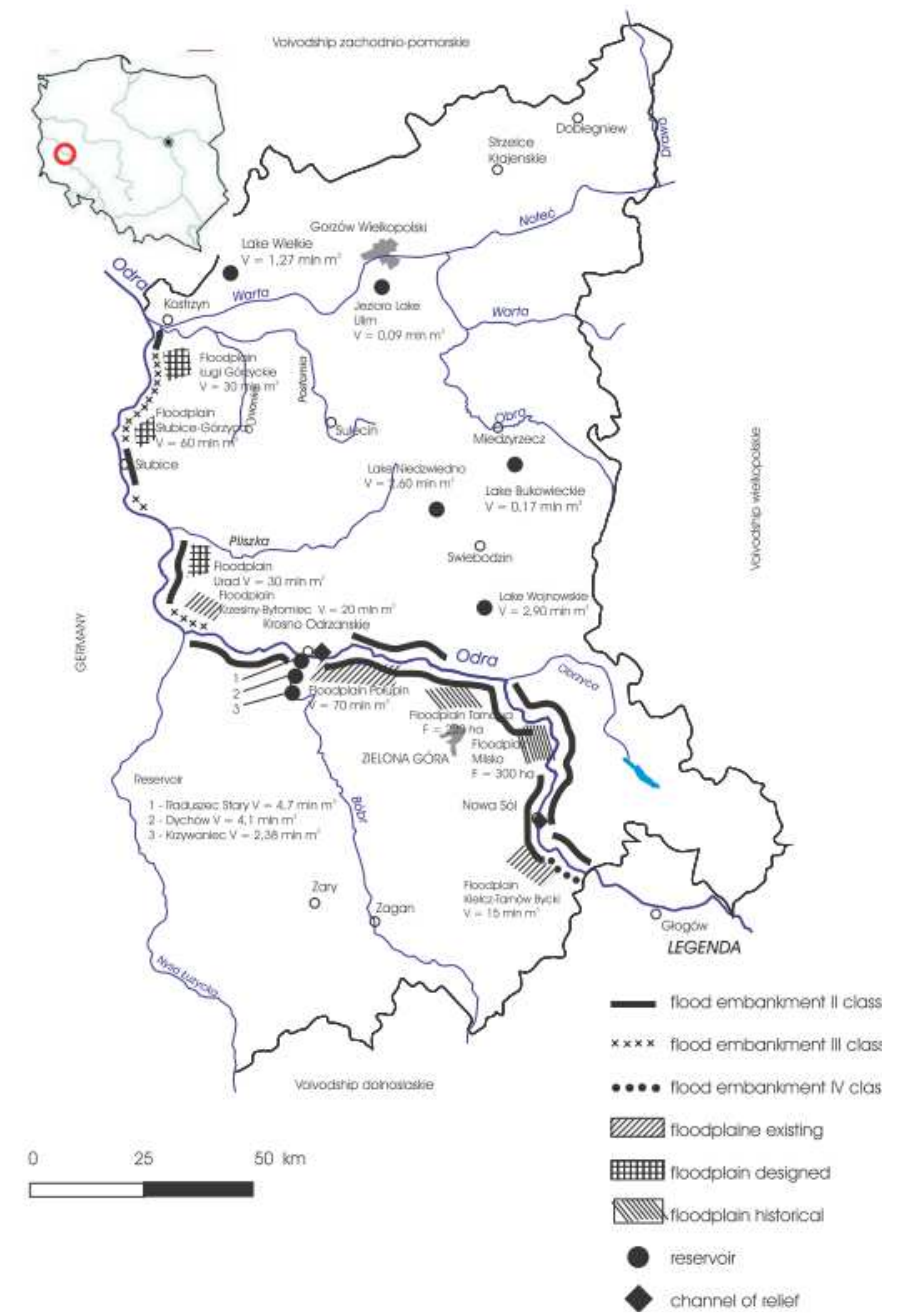

Fig. 1. Flood protection facilities in the Lubuskie Voivodship 


\section{FLOOD PROTECTION FACILITIES IN THE NOWA SÓL - CIGACICE SECTION}

The flood of 1997 exposed the lack of sufficient flood protection in our country, therefore, a number of tasks were undertaken to protect the threatened areas.

After the flood, action was taken to repair the damage with the objective being to restore the condition of the levees to before the flood. A serious obstacle to the reconstruction of the levees was the lack of access roads and the water remaining in breaches and collapses. In the first step, the breaches formed in the substrate of the levees were filled using the frontal method, which consists in dumping soil masses directly into the water and then densifying the embankment formed above the water surface. Further work consisted of removing the upper (damaged) part of the body, densifying the existing body, rebuilding the damaged parts and covering the entire body with bio-based geotextiles with grass seeds or turf. In a number of cases, geosynthetics and vibroflotation were used and the side facing the water was sealed with $1 \mathrm{~mm}$ thick PVC foil. The crown of the levee was raised from 3.0 to $5.5 \mathrm{~m}$, which is over $0.5 \mathrm{~m}$ higher than before the flood, and the angle of the slope was reduced to 1:3.5. Additionally, in some places, $4.0 \mathrm{~m}$ wide benches were built [Kolodziejczyk, Asani 2012].

Another objective was to provide flood protection for the town of Nowa Sól. This was achieved by constructing a linear structure, consisting of a body of earth with a reinforced concrete wall on it in the form of a $955 \mathrm{~m}$ long ring levee beginning in the area of the intersection between Korzeniowski Street and Żwirko and Wigura Street at the entrance to the port basin, and ending on the high ground in the south-eastern corner of the port basin [Project 2004] - Photo 1. This protective structure contributes significantly to improving the protection of the historical part of the town with an area of about 27 hectares and protects this area against direct flooding by the Odra River, even when flow rates reach a level that can only occur once in a hundred years, i.e. with a probability of $\mathrm{p}=$ $1 \%$. Another measure taken to protect the town of Nowa Sól against flooding is reconstruction, extension, and demolition of the existing structures and construction of new structures in the district of Pleszówek (left bank of the valley of the Odra River and the Czarna Struga River) [http://nowasol.pl].

The scope of the proposed investment project includes:

- extension of the left bank levee of the Odra River along a length of about $3.00 \mathrm{~km}$, in the river section: $\mathrm{km} \mathrm{429.85-432.40} \mathrm{including} \mathrm{the} \mathrm{related}$ buildings,

- regulation of the Czarna Struga river bed in the section: $\mathrm{km}$ 0.000-7.618, including expansion of the levees on both banks and the related objects,

- construction of a flood pumping station (for water from the Czarna Struga basin and water seeping through), including a pumping station canal. 


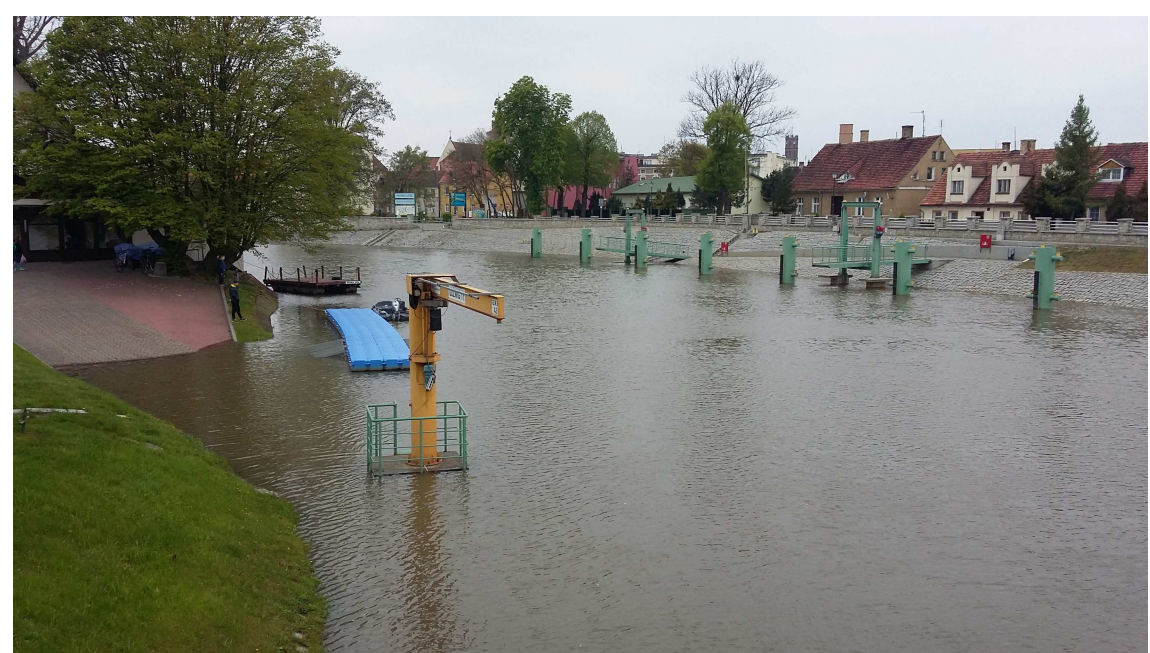

Photo. 1. The flood wall - the river port in Nowa Sól - May 2017 (Photo M. Hudak)

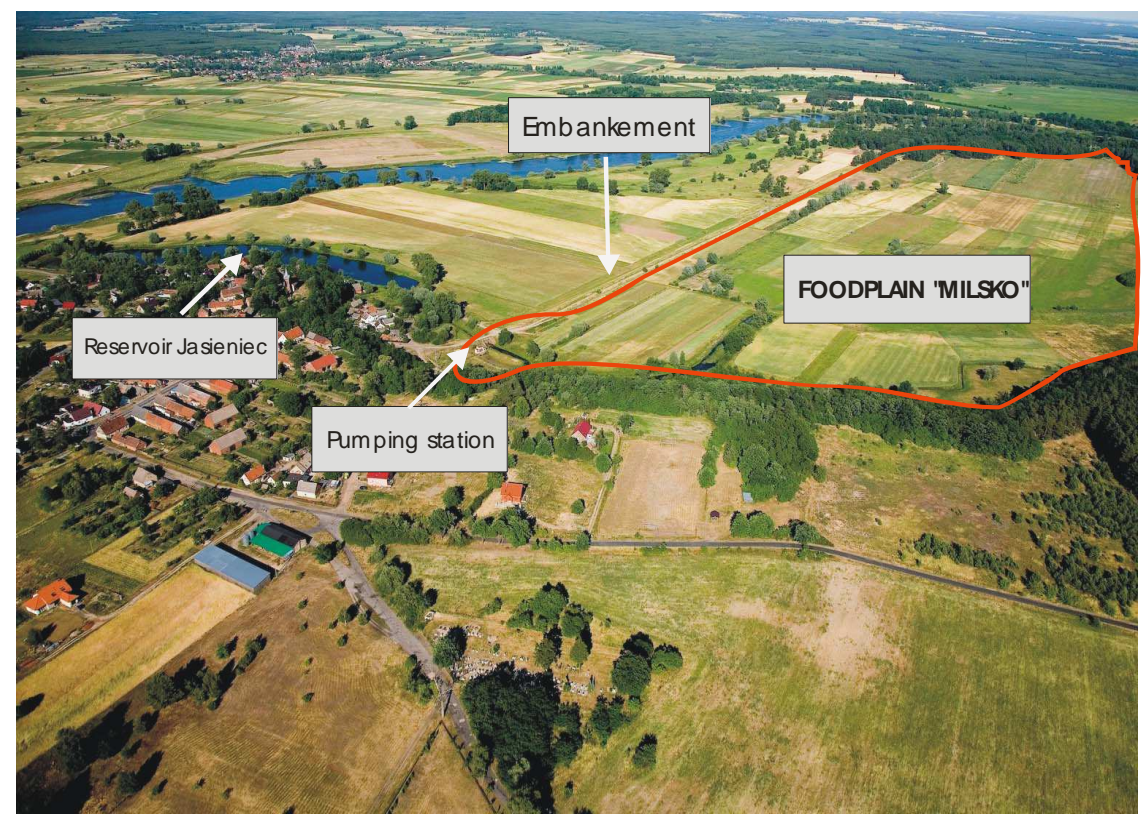

Photo. 2. Floodplain "Milsko" - April 2015 (Photo C. Karczmar)

From among the old polders, the Milsko polder is relatively easy to reactivate. The land, currently used for agriculture (Photo 2), is drained through the Jasieniec stream. At the mouth of the stream, there is a pumping station which directs the water to the canal, the Jasieniec reservoir, and then on to the Odra 
River. The capacity of the existing pumping station is $0.30 \mathrm{~m}^{3} / \mathrm{s}$ (being 2 pumps with a capacity of $0.15 \mathrm{~m}^{3} / \mathrm{s}$ each) and the impact area is about 90 hectares.

The Milsko polder will be a dry, controlled tank with an area of approximately 300 ha and an estimated capacity of 5 to 10 million $\mathrm{m}^{3}$. It will be reactivated according to the design specifications of the historical floodplain (Fig. 2), which was filled through a levee spillway. In order to reactivate the polder, it will be necessary to reconstruct the levee spillway, rebuild the pumping station, and clear the drainage canal.

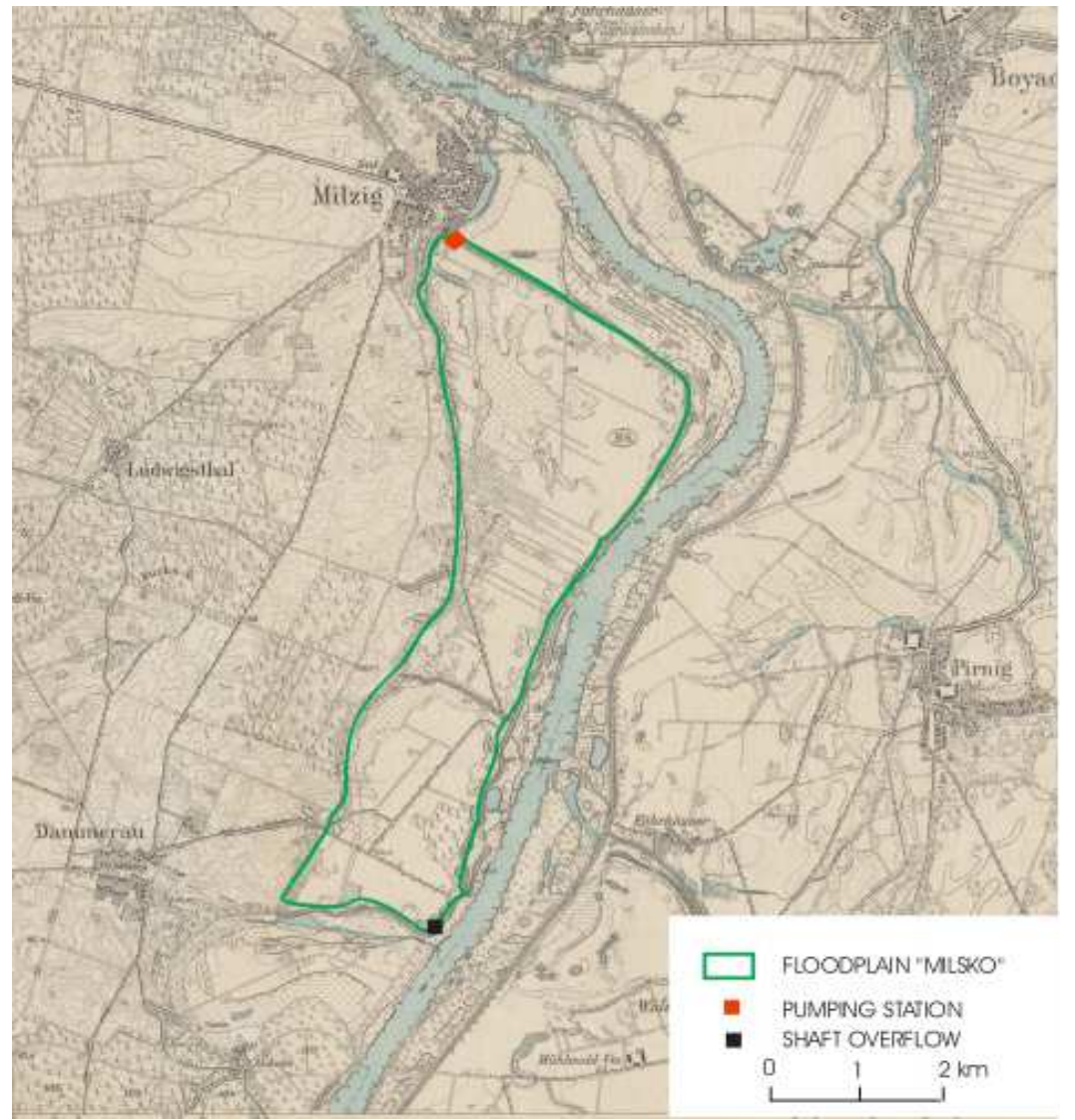

Fig. 2. Historical floodplain near Milsko [http://amzpbig.com]

It will be located between a natural slope (the moraine of the Weichselian glaciation) and the Odra River levee. The elevation of the slope ranges from 85.00 to $90.10 \mathrm{~m}$ a.s.1., and the elevation of the polder ranges from 56.50 to $59.50 \mathrm{~m}$ a.s.1. 
The height of the levee along the river sometimes reaches $4 \mathrm{~m}$ but most of it remains at $3 \mathrm{~m}$. The levee is a relatively inexpensive flood protection solution but has a negative impact on the flow of the water in the river. The cross-section of the inter-levee area is narrowed which results in an increase in the floodwater level. The levee cuts off the floodplains, which greatly reduces retention in the river valley leading to an increase in the volume of floodwaters.

\section{CONCLUSIONS}

In order to reconcile the most important idea behind the construction of the levees, which is to protect people's lives, with the hydrological and environmental requirements, it absolutely necessary to comply with levee design and construction principles. It is necessary to allow the flood wave to spill in certain places in order to reduce it. Levees should always be constructed as far from the riverbed as possible. This increases the capacity of the inter-levee area and retention in the river valley while lowering the high-water level and the flow rate of floodwaters. New polders should also be built wherever possible because they provide an opportunity to restore the unique ecosystem of the river valley and to reconcile flood protection with nature conservation.

An example of such solutions is the project to reconstruct the Milsko polder, located in the Middle Odra Region. The area, which is used today for agriculture, and drained by a local pump station, could be filled with floodwater. It is possible to gather about $10 \mathrm{~m}^{3}$ of water in it. Reconstructing the polder would require relatively little investment, consisting in rebuilding the levee spillway and the pumping station as well as clearing the drainage canal.

\section{REFERENCES}

1. Bąk K., Duda S.: Szkody i skutki powodzi w lasach zielonogórskich. W: „Ochrona i rekultywacja terenów dorzecza Odry - sytuacja po powodzi 1997 r.” Politechnika Zielonogórska 1998.

2. Bednarczyk S., Jarzębińska T., Mackiewicz S., Wołoszyn E.: Vademecum ochrony przeciwpowodziowej, Gdańsk, KZGW 2006.

3. Depczyński W., Szamowski A.: Budowle i zbiorniki wodne Warszawa, Oficyna Wydaw. Politechniki Warszawskiej 1999.

4. Kołodziejczyk U.: Geologiczno-inżynierskie badania wałów przeciwpowodziowych $i$ ich podtoża: jako metoda prognozy zagrożeń powodziowych na lubuskim odcinku Odry Zielona Góra, Oficyna Wydawnicza Uniwersytetu Zielonogórskiego 2002.

5. Kołodziejczyk U., Asani A.: Metodyka kompleksowej oceny stanu watów przeciwpowodziowych. Gospodarka Wodna, 8 (2012) 337-342. 
6. Majewski W.: Powodzie: od ochrony przeciwpowodziowej do zarzadzania powodzia. W: Materiały Seminarium „Nowe podejście do zagadnień ochrony przeciwpowodziowej”, Gdańsk, Wyd. IBW PAN 2004.

7. Mikulski Z.; 1996. Powstanie pojęcia gospodarki wodnej i jej poczatki jako dyscypliny naukowej w Polsce. Gospodarka wodna, 6 (1996) 287-291.

8. Mioduszewski W.: Gospodarka wodna w obszarach wiejskich. Przegląd Naukowy Inżynieria i Kształtowanie Środowiska, 31 (2005) 23-27.

9. Radczuk L.: Modelowanie procesów hydrologicznych $w$ dorzeczu Górnej i Środkowej Odry. Wpółczesne problemy inżynierii środowiska. Monografie LVII. Wydawnictwo Uniwersytetu Przyrodniczego we Wrocławiu 2008.

10. Rast G., Obrdlik P., Nieznański P. [red.] Atlas terenów zalewowych Odry. WWF. Deutschland 2000.

11. Tymiński T.: Hydraulic Model Investigation of Flow Conditions for Floodplains with Coniferous and Deciduous Shrubs. Polish Journal of Environmental Studies, 21, 4 (2012) 1047-1052.

12. http://amzpbig.com/maps/025_TK25/4060_Zabor_1947.jpg

13. Projekt budowlany Zabezpieczenie przeciwpowodziowe miasta Nowej Soli w rejonie basenu portowego, Biuro Projektów Inżynierii Środowiska i Melioracji „Ekoprojekt” w Zielonej Górze 2004

14. http://nowasol.pl/index.php/aktualnosci/1982-setki-milionow-nazabezpieczenie-przeciwpowodziowe

\section{ZABEZPIECZENIE PRZECIWPOWODZIOWE ODRY NA ODCINKU NOWA SÓL-CIGACICE}

\section{Streszczenie}

Stosowane od wieków sposoby zagospodarowania dolin rzecznych oraz wykorzystanie obszaru pod budownictwo mieszkalne doprowadziło do negatywnych konsekwencji dla środowiska. Przeznaczenie terenów pod rolnictwo oraz zabezpieczanie ich przed powodzią budowlami hydrotechnicznymi ograniczyło naturalny rozlew rzeki. Według prawa należy zmniejszyć ryzyko wystąpienia katastrofalnej powodzi oraz zminimalizować jej skutki.

Spójna gospodarka wodna warunkuje skuteczność ochrony przeciwpowodziowej w całym dorzeczu. Rozwiązaniem tego problemu może być odtworzenie dawnych polderów zalewowych funkcjonujących na Środkowym Nadodrzu przed 1945 r., w tym polderu Milsko.

Keywords: ochrona przeciwpowodziowa, suche poldery, poldery zalewowe

Editor received the manuscript: 06.02.2018 